\title{
SIGILII COMERCIALE DESCOPERITE LA TOMIS
}

\author{
EUGEN PARASCHIV-GRIGORE
}

\section{COMMERCIAL SEALS DISCOVERED AT TOMIS}

The author presents, in this paper, 13 Byzantine commercial lead seals discovered at Tomis during the interwar period, kept on the National Museum of Romanian History's collections. One of the 13 objects presented is a commercial imperial seal, while another one is issued by the city of Smyrna. The others 11 seals are issued by individuals whose names cannot be specified due to the objects' conservation status. A brief presentation of the Roman-Byzantine and Byzantine commercial seal findings from Dobrudja is included.

KEYWORDS: commercial seals, Byzantine era, Tomis

CUVINTE CHEIE: sigilii comerciale, epocă bizantină, Tomis

Printre artefactele descoperite ca urmare a săpăturilor arheologice sau întâmplător se numără și sigiliile. Deși nu într-o cantitate impresionantă, măruntele obiecte din plumb contribuie la o mai bună cunoaștere a perioadei bizantine pe teritoriul Dobrogei de astăzi. Este și cazul celor 13 sigilii romanobizantine ce fac obiectul prezentului studiu, descoperite la Tomis. Acestea sunt sigilii comerciale, folosite la sigilarea şi garantarea autenticităţii produselor sau pentru a face dovada plății taxelor vamale.

Sigiliile comerciale au fost emise începând cu a doua jumătate a secolului al II-lea (sigilii comerciale ale unor legiuni ımane) ${ }^{l}$ şi folosite pe scară largă în secolele al V-lea şi al VI-lea. Se pot clasifica în două tipuri distincte. În prima categorie intră sigiliile comerciale particulare (cele mai numeroase), emise de către persoane private - producători sau comercianţi - sau aparținând unor orașe (acestea din urmă fiind imprimate cu efigia sau cu numele oraşului); acest tip de sigilii are o importanţă deosebită în stabilirea reţelei de relaţii economice dintre oraşele provinciei de la gurile Dunării şi restul Imperiului. A doua categorie este alcătuită din sigiliile comerciale imperiale, emise de către atelierele imperiale sau de cele care lucrau pentru casa imperială şi aveau dreptul de a exporta anumite produse considerate monopol.

Din totalul sigiliilor romano-bizantine și bizantine descoperite până în prezent pe teritoriul dobrogean, cele comerciale reprezintă un procent însemnat $(30,25 \%)^{2}$, însumând 177 de piese, analizate şi publicate în mai multe lucrări ştiinţifice ${ }^{3}$, dintre care 157 se încadrează în categoria celor comerciale particulare. Acestea din urmă au fost descoperite pe teritoriul a cinci cetăţi din Dobrogea: Sucidava (Izvoarele) $^{4}$, Altinum (Oltina) ${ }^{5}$, Noviodunum (Isaccea) $)^{6}$, Durostorum (Silistra) ${ }^{7}$, Tomis (Constanţa) ${ }^{8}$.

$\mathrm{Nu}$ însă pentru toate sigiliile se poate determina emitentul sau zona de proveniență, în special din cauza condiţiilor de descoperire şi conservare şi a deteriorării de-a lungul timpului, dar şi a informaţiilor sumare ce puteau fỉ imprimate pe suprafaţa restrânsă a sigiliilor.

De pe teritoriul Dobrogei, până în prezent, se cunosc 25 de sigilii comerciale emise de comunităţile unor oraşe sau de entităţi bisericești ce făceau comerţ sau aveau dreptul de a face comerţ.

\footnotetext{
${ }^{1}$ Culică 1978, fig. 3

${ }^{2}$ Paraschiv 2011 , teză de doctorat (nepublicată), dintr-un total de 585 de piese.

${ }^{3}$ Barnea 1966; Barnea 1969; Bamea 1975; Barnea 1982; Bamea 1985; Barnea 1990; Bamea 1992; Barnea 1995; Bamea 1996: Bamea 1997a; Bănescu 1938; Culică 1975; Knechtel 1915; Metaxa 1915

${ }^{4}$ Sigiliile descoperite în zona Izvoarele-Pârjoaia au fost publicate de către Vasile Culică. Vezi Culică 1975 și Culică 1976.

${ }_{6}^{5}$ Barnea 1990, nr. 3

${ }^{6}$ Bamea 1975, nr. 1; Bamea 1985, nr. 4; Bamea 1990, nr. 4; Bamea 1995, nr. 6; Bamea 1996, nr. 3

${ }^{7}$ Barnea 1966, nr. 6; Barnea 1982, nr. 2

${ }^{8}$ Knechtel 1915, nr. 28-35, 37-40; Metaxa 1915, nr. la; Bamea 1992, nr. 3, 4 şi 6
} 
Importanţa acestor sigilii este cu atât mai mare, cu cât ele însoţeau mărfuri ce proveneau de la distanţe apreciabile, ceea ce atestă faptul că provincia dintre Dunăre şi Marea Neagră avea legături comerciale solide cu oraşele din întregul Imperiu, atât cu provinciile din zona europeană, cât şi cu cele micro-asiatice. Printre acestea se găsește și un sigiliu emis de mănăstirea Sfântului Euthymios cel Mare ${ }^{9}$, aflată în Palestina, ceea ce poate indica dimensiunea relațiilor comerciale pentru acea perioadă.

Cele mai multe plumburi comerciale, ale căror emitenţi se cunosc, sunt cele emise de oraşul Smyrna, 13 astfel de sigiliii ${ }^{10}$, ce au însoţit mărfuri din celebrul oraş micro-asiatic, fiind descoperite pe teritoriul dobrogean ${ }^{11}$, majoritatea la Sucidava-Izvoarele ${ }^{12}$.

Celelalte sigilii aparțin oraşelor: Ephes - trei piese ${ }^{13}$, Pamphylia - o piesă ${ }^{14}$, Chersones - două piese $^{15}$, Pergamon - o piesă ${ }^{16}$, Koloë - trei piese ${ }^{17}$, Metropolis - o piesă ${ }^{18}$, Hyperechion - o piesă ${ }^{19}$ şi o piesă de la mănăstirea sfântului Euthymios cel Mare, mai sus menționată ${ }^{20}$.

Existenţa unui număr însemnat de sigilii emise de oraşele micro-asiatice dovedeşte relaţii comerciale active cu această zonă, ce se vor prelungi de-a lungul perioadei proto-bizantine si bizantine, Asia Mică rămânând principala zonă de interes comercial a oraşelor vest pontice.

În ceea ce priveşte datarea, sigiliile comerciale descoperite în Dobrogea acoperă o perioadă întinsă de timp. Cele mai timpurii piese de acest fel sunt datate în secolul al IV-lea şi, deşi puţin numeroase, sunt de o importanţă deosebită pentru confirmarea datelor cu privire la istoria economică a provinciei Scythia Minor, începând cu perioada constantiniană.

O excepţie interesantă este reprezentată de un sigiliu comercial descoperit la Tomis $(\text { Constanţa })^{21}$ şi datat în secolele II-III p. Chr. Este un sigiliu unicat, fiind singurul provenit din Dobrogea şi datat în acest interval. Deşi este cunoscut faptul că primele sigilii de plumb apar începând cu secolul al IV-lea, nu este exclus să fi fost folosite şi înaintea acestei perioade.

Cele mai multe sigilii comerciale se încadrează, însă, în intervalul de timp cuprins între secolele al IV-lea și al VII-lea. Pentru perioada secolelor IX-XII, când teritoriul dintre Dunăre şi Marea Neagră revine sub stăpânirea Imperiului, nu se cunosc, până în prezent, decât două sigilii comerciale $^{22}$.

Sigiliile comerciale imperiale erau emise sub stricta supraveghere a curţii imperiale şi folosite pentru a asigura autenticitatea (deci, şi calitatea) produselor fabricate în atelierele imperiale. Numărul acestor piese este destul de redus, în principal datorită perioadei scurte în care a fost întrebuinţat acest tip de plumburi (acestea circulă în perioada cuprinsă între secolul al IV-lea şi începutul secolului al VII-lea), dar şi caracterului lor aparte. Cu toate acestea, valoarea lor istorică este la fel de însemnată ca și a celor comerciale private.

Cele mai multe sigilii comerciale imperiale nu se deosebesc, la prima vedere, de cele particulare, o diferenţă notabilă fiind reprezentarea portretului împăratului sau legenda ce conţine numele acestuia. De asemenea, acest tip de plumburi se remarcă prin gradul ridicat de standardizare $^{23}$.

\footnotetext{
9 Ascet palestinian ce a trăit în secolul al V-lea ( $\uparrow 473)$, a întemeiat o mare mănăstire care i-a purtat numele și a fost vestită în secolele VI-VII. Despre aceastā mănăstire, mai existā câteva infonnaţii şi în secolul al XII-lea, dar, după această dată, mănăstirca cade în ruină. Pentru mai multe informaţii, vezi Vailhé 1909, p. 140.

${ }^{10}$ Barnea 1969, nr. 1-3; Culică 1975, nr. 49-56 și 116; Bamea 1996, nr. 2

II Trei sigilii ale acestui oraş au fost descoperite pe teritoriul dobrogean, însă nu se cunoaşte locul exact de provenienţă.

1210 asemenea sigilii au fost descoperite în acest loc.

${ }^{13}$ Barnea 1969, nr. 7; Culică 1975, nr. 57; Bamea 1982, nr. 2

${ }^{14}$ Bamea 1990, nr. 3

15 Bamea 1966, nr. 6; Barnea 1996, nr. 3

${ }^{16}$ Barnea 1985, nr. 4

${ }^{17}$ Barnea 1969, nr. 4-6

${ }^{18}$ Bamea 1969, nr. 8

${ }^{19}$ Bamea 1969, nr. 9

${ }^{20}$ Bănescu 1938, nr. 7

${ }^{21}$ Metaxa 1915, nr. 1

22 Barnea 1966, nr. 6 şi Bānescu 1938, nr. 7

${ }^{23}$ Culică 1975, 231
} 
Până în prezent, se cunosc 20 de sigilii ce fac parte din această categorie și care au fost descoperite în arealul a patru situri arheologice din Dobrogea: Sucidava (Izvoarele) ${ }^{24}$, Noviodunum (Isaccea) $^{25}$, Durostorum /Dorostolon (Silistra) ${ }^{26}$, Tomis (Constanţa) ${ }^{27}$.

Cel mai timpuriu sigiliu comercial imperial este o piesă emisă de împăratul Licinius ${ }^{28}$. Plumbul, descoperit întâmplător, îl figurează pe împărat alături de fiul acestuia Licinius al II-lea şi se datează între 1 martie 317, când acesta din urmă a fost proclamat Caesar, și 18 septembrie 324, data la care Licinius este învins de Constantin cel Mare la Chrysopolis şi detronat ${ }^{29}$.

Printre cele mai timpurii sigilii comerciale imperiale descoperite pe teritoriul Dobrogei, datate la începutul secolului al IV-lea, se numără şi cele emise de împăratul Constantin cel Mare. Un sigiliu a fost descoperit la Sucidava (Izvoarele) ${ }^{30}$, un altul provine fie de la Tomis $^{31}$, fie de la Sucidava, iar un al treilea sigiliu a fost descoperit la Durostorum ${ }^{32}$. Primele două plumburi sunt identice, fiind ştanfate cu aceeaşi matriţă, ceea ce poate conduce la ipoteza că cel de-al doilea ar fi fost descoperit tot la Sucidava. Aceste două piese au fost emise imediat după anul 324, când împăratul Constantin cel Mare îl înfrânge pe Licinius ${ }^{33}$. Cel de-al treilea exemplar este o emisiune mai târzie a împăratului Constantin cel Mare, cel mai probabil din anul 330, fiind diferit faţă de celelalte două plumburi mai sus menţionate. Toate aceste trei sigilii emise de Constantin cel Mare au caracter oficial, pe teritoriul Imperiului Romano-Bizantin ${ }^{34}$ fiind descoperite mai multe piese de acest fel, datate în a doua parte a domniei, când au fost puse bazele noului imperiu şi ale unei noi capitale, iar la Dunărea de Jos s-a intensificat politica de apărare şi s-a trecut la o politică ofensivă, de recucerire a teritoriilor dunărene. Limes-ul dunărean devine, o dată cu construcţia noii capitale, cea mai înaintată linie defensivă a acesteia, iar Scythia Minor va juca un rol important în sistemul de apărare al imperiului. Pe lângă rolul militar, provincia dunăreană îşi recapătă şi rolul economic (dovedit şi de descoperirile de sigilii comerciale), mai ales după anul 332, când Constantin cel Mare semnează un tratat de pace şi alianţă (foedus) cu goţii de la nord de Dunăre, restabilind astfel pacea la frontiera de nord a Imperiului ${ }^{35}$.

Din a doua jumătate a secolului al IV-lea, se păstrează două sigilii asemănătoare, doar unul cu loc de descoperire cert - Tomis. Primul a fost emis de către împăratul Valentinian I (364-375) ${ }^{36}$, iar cel de-al doilea de Theodosius I (379-395) ${ }^{37}$. Pe ambele sigilii, împăraţii sunt reprezentaţi alături de fii acestora, Valentinian fiind figurat alături de Valens şi Gratian, iar Theodosius, alături de Arcadius şi Honorius. Deşi aflate într-o stare precară de conservare, legendele ce însoţeau imaginile fiind șterse în totalitate, atribuirea acestor sigilii este certă.

Un alt plumb ce poate fi atribuit cu certitudine unui împărat, datează din secolul al VI-lea şi este o emisiune a împăratului Iustinian (527-565). De asemenea, este singura piesă de acest tip, cunoscută până acum, ce provine din descoperirile de la Noviodunum ${ }^{38}$. Alte sigilii asemănătoare, emise de acest impărat, au mai fost descoperite la Tomis $^{39}$ şi Durostorum ${ }^{40}$, însă sunt mai degrabă plumburi imperiale folosite la sigilarea corespondenței sau la autentificarea actelor, decât sigilii comerciale.

Un alt plumb, descoperit la Sucidava şi atribuit împăratului Iustinian ${ }^{41}$, prezintă pe ambele feţe câte o monogramă cruciformă ce se întregește probabil cu numele acestuia. Sigiliul a fost datat de

${ }^{24}$ Culică 1975. nr. 1-4, 69-74, 103 şi 122

${ }^{25}$ Barnea 1985, nr. 2

${ }^{26}$ Bamea 1982, nr. 1

${ }^{27}$ Barnea 1990, nr. 1; Knechtel 1915, nr. 26, 36

${ }^{28}$ Barnea 1996, nr. I

${ }^{29}$ Barnea, Iliescu 1982, nr. 42, 44

${ }^{30}$ Culică 1975, nr. 1

${ }^{31}$ Barnea 1985, nr. 1

${ }^{32}$ Barnea 1982, nr. I

${ }^{33}$ Barnea 1985, 236-237

${ }^{34}$ Rostovţev 1897, 478, nr. 1-3

${ }^{35}$ Bamea, Iliescu 1982, 107 şi următoarele

${ }^{36}$ Barnea 1997a, nr. 1

${ }^{37}$ Bamea 1990, nr. I

${ }^{38}$ Barnea 1985, nr. 2

${ }^{39}$ Bamea 1984, nr. 1; Knechtel 1915, nr. 2 și 8

${ }^{40}$ Barnea 1982, nr. 3

${ }^{41}$ Culică 1975, nr. 69 
primul editor ca fiind emis la sfârşitul secolului al V-lea, începutul secolului al VI-lea ${ }^{42}$, însă atribuirea sa împăratului Iustinian este certă şi, prin urmare, sigiliul se datează cu siguranță în secolul al VI-lea.

Din cele 20 de sigilii comerciale imperiale cunoscute și publicate până în prezent, 12 nu pot fi atribuite cu certitudine anumitor împăraţi, deoarece elementele de identificare nu s-au păstrat. Dintre acestea, zece plumburi au fost descoperite la Sucidava ${ }^{43}$, iar două provin de la Tomis $^{44}$.

Pentru perioada bizantină, până în momentul de faţă, nu se cunoaşte niciun sigiliu comercial imperial descoperit pe teritoriul themei Paradunavon (Paristrion), fapt ce întăreşte afirmaţia conform căreia, în perioada bizantină, sigiliul de plumb era folosit cu precădere la sigilarea corespondenței şi a actelor oficiale.

Celor 177 sigilii comerciale prezentate succint în rândurile de mai sus li se adaugă 13 plumburi păstrate în colecția Muzeului Naţional de Istorie a României (MNIR), descoperite la Tomis între anii 1925 și 1930. Acestea au făcut parte din colecția maior Ştefan Nicolae și au fost donate muzeului în anul 1979. Toate cele 13 piese sunt sigilii comerciale (unul fiind sigiliu comercial imperial - nr. cat. 10) şi se adaugă celorlalte sigilii de acest tip descoperite la Tomis ${ }^{45}$ până în prezent. Prin urmare, numărul total al pieselor descoperite pe teritoriul dobrogean ajunge la 190, iar dintre acestea 33 de sigilii comerciale au fost descoperite la Tomis.

Cele mai multe dintre sigiliile prezentate în catalogul de mai jos sunt într-o stare de conservare precară, ceea ce face imposibilă descifrarea legendelor și, deci, atribuirea lor anumitor personaje.

Sigiliile prezentate la nr. cat. 6 și 7 au pe avers monograma lui Hristos (XP) fiind printre puținele descoperiri de acest fel de pe teritoriul Dobrogei. Un sigiliu asemănător a mai fost publicat de I. Barnea ${ }^{46}$ și se află tot în colecțiile MNIR (nr. inv. 131073). Un al patrulea sigiliu cu monograma lui Hristos este publicat în 1915 de către W. Knechtel, fiind primul plumb de acest fel descoperit pe teritoriul dobrogean ${ }^{47}$. Cele patru sigilii nu sunt identice, fiind deci confecționate cu matrițe diferite.

Piesa cu numărul de catalog 9 (emisă de oraşul Smyrna) se adaugă celorlalte zece sigilii descoperite la Sucidava ${ }^{48}$ şi altor trei descoperite în aşezări dobrogene ${ }^{49}$. În total se cunosc 14 plumburi emise de oraşul Smyrna, descoperite pe teritoriul dobrogean, reprezentând cele mai multe emisiuni ale unui oraş, descoperite în Dobrogea. Putem considera, deci, acest fapt, ca o dovadă de necontestat a strânsei legături dintre așezările din Dobrogea şi oraşul anatolian, în perioada cuprinsă între secolul al V-lea şi secolul al VI-lea.

Sigiliul comercial imperial (nr. cat. 10) este o piesă ce se alătură celor patru plumburi emise de către împăraţii Theodosius I, Arcadius şi Honorius descoperite la Sucidava ${ }^{50}$. Este al doilea sigiliu comercial imperial descoperit până în prezent la Tomis, fiind similar cu cel publicat de Ion Barnea și păstrat, de asemenea în colecţia MNIR ${ }^{5 !}$.

Un sigiliu comercial identic cu nr. cat. 12 a fost descoperit la Sucidava-Izvoarele ${ }^{52}$, ambele au fost imprimate cu același clește. Sigiliul prezintă pe avers un leu cu coamă deasă și coada lungă, ridicată în sus, mergând spre dreapta, răgând. Deasupra leului, cu litere greceşti şi latineşti, este imprimată o legendă circulară, cel mai probabil cu numele emitentului. Elemente zoomorfe se întâlnesc și pe sigiliul nr. cat. 3 (într-un cerc perlat se distinge un cal păşind spre dreapta; datorită deteriorării piesei capul calului nu se mai distinge; piciorul stâng față al calului se află ridicat - la trap) și pe plumbul de la nr. cat. 8 (într-un cerc perlat imaginea unei păsări, puțin vizibilă; pasărea cu capul spre dreapta și coadă stufoasă - cel mai probabil, un păun). Prezența elementelor zoomorfe pe sigiliile bizantine nu este un lucru inedit, fiind întâlnite multe astfel de exemple. Cele mai răspândite animale

\footnotetext{
${ }^{42}$ Culică 1975, nr. 69

${ }^{43}$ Culică 1975 , nr. 2, 3, 4, 70, 71, 72, 73, 74, 103, 122

${ }^{44}$ Knechtel 1915, nr 26 şi 36

${ }^{45}$ Barnea 1990, nr. 1; Metaxa 1915, nr. 1a; Knechtel 1915, nr. 26, 28-40; Bamea 1992, nr. 3, 4 și 6; Barnea 1997 b, nr. 4

${ }^{46}$ Barnea 1992, nr. 6

${ }^{47}$ Kncchtel 1915, nr. 37

${ }^{48}$ Culică 1975, nr. 49-56, 116; Bamea 1996, nr. 2

${ }^{49}$ Bamea 1969, nr. 1-3

${ }^{50}$ Culică 1975, 246-249 și 251-253, nr. 70-72 și 103

${ }^{5 !}$ Bamea 1990, nr. 1. Deși autorul prezintă sigiliu ca şi cum acesta s-ar afla la Institutul de Arheologie „Vasile Pârvan" din Bucureşti, el se aflā în colecțiile MNIR cu nr. inv. 131060.

52 Culică 1975, nr. 85, Paraschiv 2011, nr. 144 (teză de doctorat)
} 
reprezentate pe sigilii sunt: șarpele ${ }^{53}$, leul ${ }^{54}$, vulturul ${ }^{55}$ sau acvila ${ }^{56}$, calul ${ }^{57}$, iepurele ${ }^{58}$ sau diferite păsări ${ }^{59}$. Faptul că sigilii identice (în alte cazuri asemănătoare) au fost descoperite în mai multe așezări din Dobrogea (cum este cazul de faţă, la Izvoarele și la Tomis), atestă că mai multe centre urbane aveau un rol însemnat în comerțul din zona pontică și că transportul pe apă reprezenta, în acea perioadă, principalul mod de comerț în această zonă. Vasele cu produse nu acostau doar la Tomis pentru ca mai apoi mărfurile să fie transportate pe uscat, ci avansau pe Dunăre până în zona SucidavaIzvoarele/Durostorum. Cel mai probabil, oraşele din interiorul dobrogean erau aprovizionate cu produse din afara provinciei prin cele mai apropiate porturi, iar transportul către așezările din interiorul provinciei se făcea pe uscat.

Piesa de la nr. cat. 13 este un sigiliu comercial emis de un oarecare Ioannes (aversul prezintă o monogramă bloc cu numele emitentului, însă foarte puțin lizibilă). Nu este singurul sigiliu comercial emis de persoane private ${ }^{60}$, dar este cu siguranţă un sigiliu comercial datorită formei piesei. Sigiliile de formă conică (cu legendă doar pe o parte a plumbului) sunt folosite exclusiv pentru sigilarea mărfurilor, fiind caracteristice perioadei cuprinse între secolul al V-lea şi secolul al VII-lea. Plecând de la această constatare, se poate afirma cu precizie că și această piesă este un sigiliu comercial.

Restul pieselor prezentate în catalogul ce însotește acest studiu nu au putut fi atribuite unor entităţi bine definite, ca urmare, după cum am menționat anterior, gradului de deteriorare foarte pronunf̧at al sigiliilor.

CATALOG $^{61}$

\section{Anonim. Tomis (Constanța).}

MNIR. $131051^{62}$. Sigiliu conic; tocit; rupt la extremitatea de jos a canalului pentru şnur; canalul pentru șnur pe direcția $\mathrm{N}-\mathrm{S}$; presare; $\mathrm{dm}=13,5 \mathrm{~mm} ; \mathrm{dc}=11,0 \mathrm{~mm} ; \mathrm{gr}=6,0 \mathrm{~mm} ; \mathrm{g}=3,33 \mathrm{~g}$.

Avers: imagine şi legendă. $\mathrm{Ca}$ urmare a deteriorării plumbului, legenda şi figura ce se aflau imprimate pe avers nu se mai păstrează. Cel mai probabil, aversul prezenta un personaj însoțit de o legendă circulară pe marginea sigiliului.

Revers: suprafaţa uşor convexă, prin care trece canalul pentru şnur.

Datare: sec. VI. PI. I/1.a-b

2. Anonim. Tomis (Constanța).

MNIR. 131054. Sigiliu monetiform; tocit; canalul pentru șnur pe direcția N-S; presare; $\mathrm{dm}=16,0 \mathrm{~mm}$; $\mathrm{dc}=14,0$ $\mathrm{mm} ; \mathrm{gr}=8,5 \mathrm{~mm} ; \mathrm{g}=4,13 \mathrm{~g}$.

Avers: imagine și legendă. Ca urmare a deteriorării piesei, nu se mai distinge nimic din imaginea de pe avers şi nici din legenda ce o însoțea.

Revers: suprafaţa ușor convexă, prin care trece canalul pentru şnur.

Datare: sec. VI. PI. I/2.a-b

3. Anonim. Tomis (Constanța).

MNIR. 131057. Sigiliu conic; deformat în urma presării plumbului; canalul pentru şnur pe direcţia N-S; presare; $\mathrm{dm}=20,0 \mathrm{~mm}, \mathrm{dc}=17,0 \mathrm{~mm}, \mathrm{gr}=6.0 \mathrm{~mm} ; \mathrm{g}=5.95 \mathrm{~g}$.

Avers: imagine și legendă. Într-un cerc perlat; se distinge un cal mergând spre dreapta. Ca urmare a deteriorării piesei, capul calului nu se mai distinge. Piciorul stâng față al calului se află ridicat (la trap). Exista probabil și o

${ }^{53}$ Culică 1975, nr. 24-26, 36, 110, 114, 130; Bănescu 1938, nr. 5; Knechtel 1915, nr. 35

${ }^{54}$ Culică 1975, nr. 31, 34, 41, 82, 84, 85, 127; Bamea 1969, nr. 19; Bamea 1997b, nr. 8

${ }^{5 s}$ Bănescu 1938, nr. 1-3; Culică 1975, nr. 31, 32; Barnea 1975, nr. 2; Bamea 1984, nr. 2 și 3; Knechtel 1915, nr. 23

${ }^{56}$ Barnea 1966, nr. 1; Knechtel 1915, nr. 7

${ }^{57}$ Metaxa 1915, nr. 6; Culică 1975, nr. 44; Knechtel 1915, nr. 23-25; Barnea 1969, nr. 22

${ }^{58}$ Knechtel 1915 , nr. 40.

${ }^{59}$ Culică 1975, nr. 33, 112, 119, 127; Bănescu 1938, nr. 5; Knechtel 1915, nr. 34

${ }^{60}$ Barnea 1966, nr. 6

${ }^{61}$ Catalogul este alcătuit după următoarea structură: emitentul; demnitatea emitentului; locul descoperinii; locaţia actuală; numărul de inventar; date tehnice; tehnica prelucrăni; dimensiunile; limba în care a fost scrisă legenda; descrierea aversului; tip legendă (unde este cazul); descrierea reversului; tip legendã (unde este cazul); comentarii specifice sigiliului (dacã este cazul); datarea sigiliului; bibliografie; planşa. În cazul în care nu sunt cunoscute toate datele, s-a fãcut precizarea lipsei lor. Descrierea sigiliilor s-a făcut din perspectiva privitorului. Prescurtările folosite în catalog sunt: $\mathrm{dm}=$ diametrul maxim, dc $=$ diametrul câmpului, gr = grosimea și $\mathrm{g}=$ greutatea.

62 Sigiliile au fost ordonate crescător după numărul de inventar pe care îl au acestea în evidența MNIR. 
legendă circulară, din care nu se mai distinge nicio literă.

Revers: Suprafał̧a uşor convexă, prin care trece canalul pentru şnur.

Datare: sec. VI. PI. I/3.a-b

4. Anonim. Tomis (Constanța).

MNIR. 131058. Sigiliu conic; deformat în urma presării; canalul pentru şnur pe direcția N-S; deteriorat la extremitățile canalului pentru şnur; presare; $\mathrm{dm}=16,5 \mathrm{~mm}, \mathrm{dc}=7,0 \mathrm{~mm}, \mathrm{gr}=9,0 \mathrm{~mm} ; \mathrm{g}=4,53 \mathrm{~g}$.

Avers: imagine și legendă. Într-un cerc, descentrat datorită presării plumbului în matrice, se afla o imagine însoțită de o legendă. Ca urmare a deteriorăni plumbului la ruperea de pe produs, nu se mai distinge nici imaginea şi nici legenda ce îl însoțea.

Revers: suprafaţa uşor convexă, prin care trece canalul pentru şnur.

Datare: sec. VI. PI. I/4.a-b

\title{
5. Anonim. Tomis (Constanța).
}

MNIR. 131066. Sigiliu conic; rupt la extremitățile canalului pentru şnur; canalul pentru şnur pe direcţia NV-SE; presare; $\mathrm{dm}=17,5 \mathrm{~mm} ; \mathrm{dc}=14,0 \mathrm{~mm} ; \mathrm{gr}=4.5 \mathrm{~mm} ; \mathrm{g}=4.14 \mathrm{~g}$. Greacă.

Avers: legendă. Într-un cerc perlat, o legendă metrică pe două rânduri, din care se mai păstrează două litere pe primul rând și o a treia literă pe rândul al doilea. Ca urmare a deteriorării piesei, legenda nu poate fi întregită.

$$
\text { ...HI/..O }
$$

Revers: suprafał̧a ușor convexă, prin care trece canalul pentru şnur.

Datare: sec. V-VI. PI. I/5.a-b

6. Anonim. Tomis (Constanţa).

MNIR. 131075. Sigiliu conic; neregulat, canalul pentru şnur pe direcţia NV-SE; presare; $\mathrm{dm}=19,0 \mathrm{~mm} ; \mathrm{dc}=$ $14,0 \mathrm{~mm} ; \mathrm{gr}=7,5 \mathrm{~mm} ; \mathrm{g}=7,14 \mathrm{~g}$. Greacă.

Avers: Monogramă. În centrul a două cercuri concentrice, monograma lui Hristos (XP).

\author{
$X P$

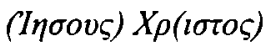 \\ Inoovৎ Xolotos \\ Iisus Hristos.
}

Revers: suprafaţa ușor convexă, prin care trece canalul pentru şnur.

Datare: sec. VI. PI. I/6.a-b

7. Anonim. Tomis (Constanța).

MNIR. 131083. Sigiliu conic; neregulat, canalul pentru şnur pe direcţia NV-SE; presare; $\mathrm{dm}=23,0 \mathrm{~mm} ; \mathrm{dc}=11,0$ $\mathrm{mm} ; \mathrm{gr}=6,3 \mathrm{~mm} ; \mathrm{g}=3,40 \mathrm{~g}$. Greacă.

Avers: Monogramă. În centrul a două cercuri concentrice perlate, monograma lui Hristos (XP).

$$
X P
$$

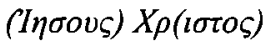

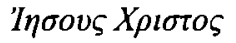

$$
\begin{aligned}
& \text { Iisus Hristos. }
\end{aligned}
$$

Revers: suprafaţa ușor convexă, prin care trece canalul pentru şnur.

Datare: sec. VI. PI. II/7.a-b

\section{Anonim. Tomis (Constanța).}

MNIR. 131092. Sigiliu conic; canalul pentru şnur pe direcţia N-S; deteriorat la extremitatea de S a canalului pentru șnur; tocit; presare; $\mathrm{dm}=21,0 \mathrm{~mm} ; \mathrm{dc}=13,0 \mathrm{~mm} ; \mathrm{gr}=6,0 \mathrm{~mm} ; \mathrm{g}=5,38 \mathrm{~g}$.

Avers: imagine și legendă. Într-un cerc perlat, imaginea unei păsări, foarte ștearsă, precum şi o legendã circulară, din care nu se mai păstrează nicio literă. Pasărea cu capul spre dreapta și coadă stufoasă (păun?).

Revers: suprafaţa ușor convexă, prin care trece canalul pentru şnur.

Datare: sec. V-VI. II/8.a-b

\section{Smyrna. Tomis (Constanța).}

MNIR. 131096. Sigiliu monetiform; câmpul legendei are formă dreptunghiulară, ceea ce a fãcut ca mare parte din legendă să cadă în afara plumbului. Canalul pentru şnur pe direcţia $\mathrm{N}-\mathrm{S}$; tocit; presare; $\mathrm{dm}=19,0 \mathrm{~mm}$; dc $=$ $13,0 \mathrm{~mm} ; \mathrm{gr}=8,5 \mathrm{~mm} ; \mathrm{g}=12,48 \mathrm{~g}$.

Avers: legendă. Legendă pe două rânduri, în chenar de formă aproximativ dreptunghiulară. Mare parte din legendă nu se mai distinge, din cauza deteriorării piesei la rupere, dar și a faptului că, probabil, câmpul gravat era mai mic decât matricea legendei. Metrică pe două rânduri.

$$
\begin{gathered}
\cdots \mid P N A \\
{[\Sigma \mu \dot{v}] \mid \rho v \alpha \alpha} \\
\Sigma \mu \dot{0} p v \alpha . \\
\text { Smyrna. }
\end{gathered}
$$

Revers: Suprafaţa convexă, prin care trece canalul pentru şnur. 
Mai multe sigilii emise de orașul Smyrna au fost descoperite pe teritoriul dobrogean, la Sucidava (Izvoarele) ${ }^{63}$ precum şi în alte localitățí.

Datare: sec. V-VI. II/9.a-b

10. Theodosius I, Arcadius şi Honorius. Împărați. Tomis (Constanța).

MNIR. 131104. Sigiliu monetiform; rupt; canalul pentru șnur pe direcția N-S; deteriorat la extremitățile canalului pentru şnur; presare; $\mathrm{dm}=20,0 \mathrm{~mm} ; \mathrm{dc}=18,0 \mathrm{~mm} ; \mathrm{gr}=3,0 \mathrm{~mm} ; \mathrm{g}=3,92 \mathrm{~g}$. Anepigraf.

Avers: imagine. Trei busturi din față, alăturate, unul mai mare, în mijloc şi două mai mici, în stânga şi în dreapta, cel din mijloc poartã diademã.

Revers: sub formă boltită, perforat la bază de canalul pentru şnur.

Patru plumburi comerciale asemănătoare, dar nu identice cu cel de faţă, s-au descoperit la Izvoarele, jud. Constanța, unde se presupune că a fost cetatea romano-bizantină Sucidava ${ }^{65}$. Un al cincilea sigiliu a fost descoperit într-o localitate dobrogeană necunoscută (dar poate fi vorba de Tomis) și se află tot în colecțiile Muzeului Național de Istorie a României (nr. inv. 131060) ${ }^{66}$. Piesa de față seamănă foarte bine cu sigiliul comercial publicat de I. Bamea în $1990^{67}$ (este posibil ca aceste două piese să fi fost imprimate cu aceeași matrice şi în aceeași perioadă), prin urmare atribuirea sigiliului perioadei cuprinse între anii 393 şi 395, când alături de Theodosius I se aflau asociați și fii acestuia Arcadius şi Honorius ${ }^{68}$, este corectă.

Datare: 393-395. II/10.a-b.

11. Anonim. Tomis (Constanța).

MNIR. 131105. Sigiliu conic; canalul pentru şnur pe direcția N-S; deteriorat la extremitatea de $\mathrm{S}$ a canalului pentru şnur; presare; $\mathrm{dm}=15,0 \mathrm{~mm} ; \mathrm{dc}=13,5 \mathrm{~mm} ; \mathrm{gr}=5,5 \mathrm{~mm} ; \mathrm{g}=3,99 \mathrm{~g}$

Avers: cruce şi legendă. Într-un cerc, în centru, o cruce în relief. În cele patru cadrane pe care le formează brațele crucii, au existat mai multe litere ce formau o legendă. Din cauza tocirii piesei, această legendă nu se mai distinge.

Revers: suprafaţa convexă, prin care trece canalul pentru şnur.

Datare: sec. V-VI. II/11.a-b.

12. Anonim. Tomis (Constanța).

MNIR. 131106. Sigiliu conic; deteriorat, rupt; rupt în mare partea pe partea dreaptă a aversului; canalul pentru şnur pe direcția N-S; presare; $\mathrm{dm}=20,0 \mathrm{~mm} ; \mathrm{dc}=17,0 \mathrm{~mm} ; \mathrm{gr}=8,5 \mathrm{~mm} ; \mathrm{g}=5,86 \mathrm{~g}$; greacă; grecești şi latine.

Avers: imagine şi legendă. Leu cu coamă deasă şi coada lungă, ridicată în sus, mergând spre dreapta, răgând.

Deasupra leului, cu litere grecești şi latineşti, o legendă circulară.

$\Pi A V \Phi$.

$\Pi \alpha v \varphi[v]$

Revers: suprafața convexă, prin care trece canalul pentru şnur. Un sigiliu identic a mai fost descoperit la Sucidava ${ }^{69}$.

Datare: sec. V-VI. II/12.a

13. Ioannes. Tomis (Constanța).

MNIR. 131108. Sigiliu conic; rupt la extremitățile canalului pentru şnur; canalul pentru şnur pe direcţia NV-SE; presare; $\mathrm{dm}=18,0 \mathrm{~mm} ; \mathrm{dc}=13,0 \mathrm{~mm} ; \mathrm{gr}=13,0 \mathrm{~mm} ; \mathrm{g}=7,88 \mathrm{~g}$; greacă; grecești.

Avers: monogramă. Într-un cerc se aflã imprimatã o monogramă bloc, ce nu se distinge din cauza deteriorării plumbului (descentrată spre stânga). Pare a fi litera N, de care sunt legate alte litere ce nu se mai disting:

\section{$\cdots N \cdot \cdots$

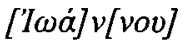

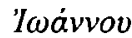 \\ Al lui loannes}

Revers: Suprafaţa convexă, prin care trece canalul pentru şnur.

Monograma de pe avers este asemănătoare cu cea de pe două sigilii descoperite, unul la Noviodunum ${ }^{70}$, iar cel de al doilea la Tomis $^{71}$ şi datate în secolul al VI-lea.

Datare: sec. VI. II/13.a-b

${ }^{63}$ Culică 1975, nr. 49-56, 116; Barnea 1996, nr. 2

${ }^{64}$ Bamea 1969, nr. 1-3

${ }^{65}$ Culicā 1975, p. 246-249 și 251-253, nr. 70-72 și 103

${ }^{66}$ Barnea 1990, nr. 1

${ }^{67}$ Barnea 1990, nr. 1

${ }^{68}$ Iliescu 1965, 276

${ }^{69}$ Culică 1975, nr. 85; Paraschiv 2011, nr. 144

${ }^{70}$ Barnea 1995, nr. 8 (revers)

${ }^{71}$ Barnea 1984, nr. 8 (avers) 


\section{BIBLIOGRAFIE}

Barnea 1966

Bamea 1969

Bamea 1975

Barnea 1982

Bamea 1984

Bamea 1985

Bamea 1990

Barnea 1992

Bamea 1995

Barnea 1996

Bamea 1997a

Barnea 1997b

Barnea, Iliescu 1982

Bănescu 1938

Culică 1975

Culică 1976

Culică 1978

Iliescu 1965

Knechtel 1915

Metaxa 1915

Paraschiv 2011

Rostovtev 1897

Vailhé 1909

LIST OF ILLUSTRATION

Pl. I-II. Commercial seals discovered at Tomis - photo George Nica p. 21-33 201-211 România, SCN, VIII, 1984, p. 95-104 1992, p. 281-296 Bucureşti, SCN, 11, 1997, p. 183-189 5,1938 , p. 115-126 Pontica, XI, 1978, p. 113-122 de doctorat) série, tom. Ier, Paris, 1897
I. Bamea, Noi sigilii bizantine de la Dunărea de Jos, $S C I V A, 17,1966$, 2, p. 277-297

I. Bamea, Plombs byzantins de la collection Michel C. Soutzo, RÉSEE, 7, 1, 1969,

I. Bamea, Sigilii bizantine de la Noviodunum (II), SCN 6, 1975, p. 159-162

I. Bamea, Sigilii bizantine de la Durostorum-Dorostolon, Pontica, 15, 1982, p.

I. Bamea, Sigilii bizantine din colecţia Muzeului de Istorie al Republicii Socialiste

I. Bamea, Sigilii bizantine inedite din Dobrogea (II), Pontica, 18, 1985, p. 235-248

I. Bamea, Sigilii bizantine inedite din Dobrogea (III), Pontica, 23, 1990, p. 315-334

I. Bamea, Unnedierte byzantinische Bleisiegel aus Tomis-Constanța, Pontica, 25 ,

I. Bamea, Sceaux byzantines inédits de Dobroudja, $S B S, 4,1995$, p. 97-100

I. Barnea, Sigilii bizantine din Dobrogea, $S C I V A, 47,1996,2$, p. 215-220

I. Bamea, Dobrogea în epoca dominatului. Organizarea administrativă, în Fafetele Istoriei (Existente, identităti, dinamici) - omagiul Academicianului Ştefan Ştefãnescu, Bucureşti, 2000, p. 279-291

I. Barnea, Sigilii bizantine din colecţia Muzeului Naţional de Antichităţi din

I. Barnea, O. Iliescu, Constantin cel Mare, București, 1982

N. Bănescu, O colecţie de sigilii bizantine inedite, $A A R M S I$, Seria III, t. XX, Mem.

V. Culică, Plumburi comerciale din cetatea romano-bizantină de la Izvoarele (Dobrogea), Pontica, VIII, 1975, p. 215-262

V. Culică, Plumburi comerciale din cetatea romano-bizantină de la Izvoarele (Dobrogea), Pontica, IX, 1976, p. 115-134

V. Culică, Cu privire la lagărul Legiunii a XI-a Claudia la Dunărea de Jos,

O. Iliescu, Nouvelles informations relatives aux lingots romains d'or trouvés en Transylvanie, RÉSEE, III, 1965, 1-2, p. 122-132

W. Knechtel, Plumburi bizantine, $B S N R$, XII, 1915, nr. 24, p. 80-97

H. Metaxa, Plumburi de marcã de la Tomi, $B C M I$, VIII, 1915, p. 31-35

E. Paraschiv, Sigilii romane târzii şi bizantine din Dobrogea, București, 2011 (teză

M.I. Rostovţev, Étude sur les plombs antiques, în Revue Numismatique, IVème

S. Vailhé, Saint Euthyme le grand moine de Palestine 376-473, Revue de l'Orient Chrétien, t. XII-XIV (1907-1909), Paris, 1909 


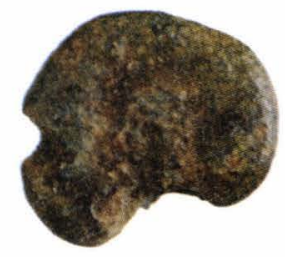

a.

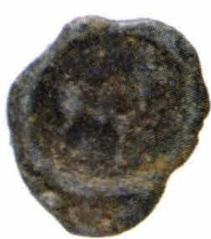

a.

3.

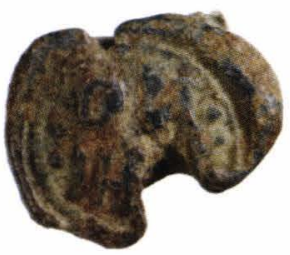

a.

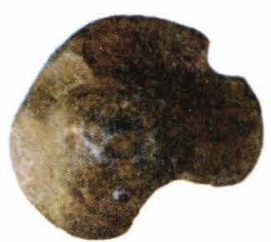

b.

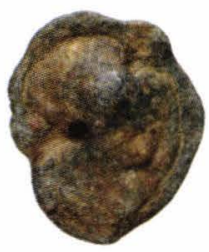

b.

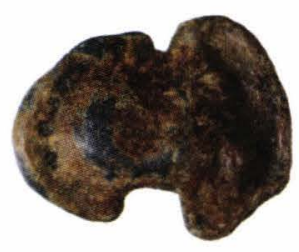

b

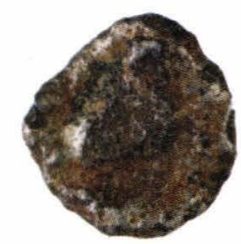

a.

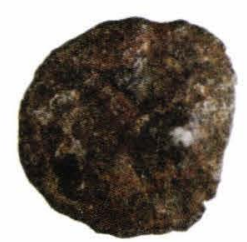

b.

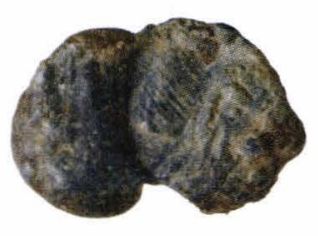

a.

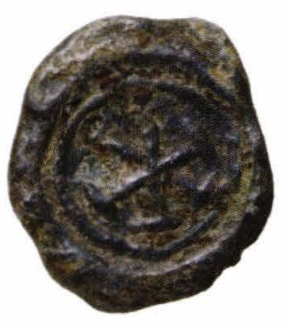

a b.
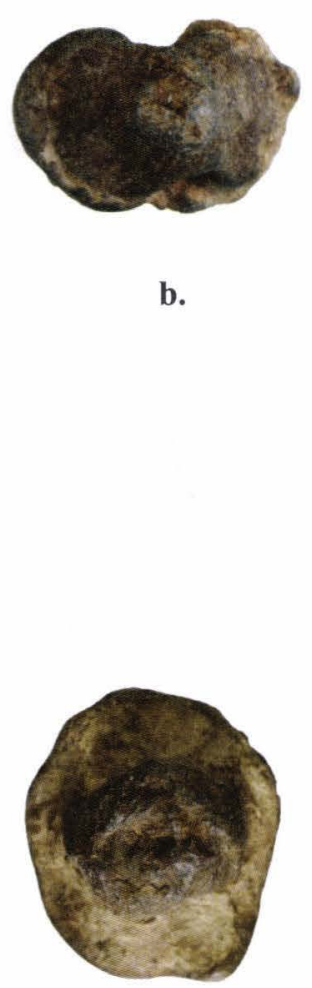

b
5.

Sigilii comerciale de la Tomis, nr. cat. 1-6 


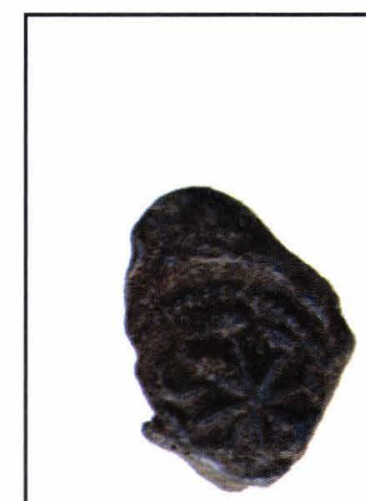

a.

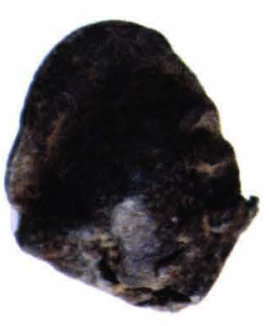

b.

7.

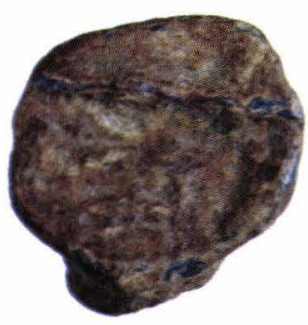

a.
9.

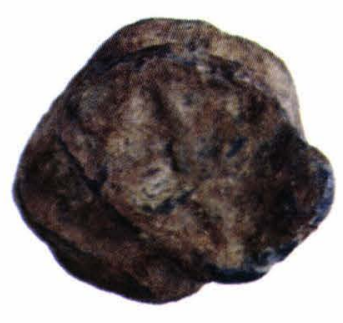

b.

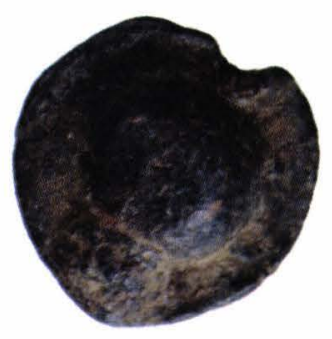

b.

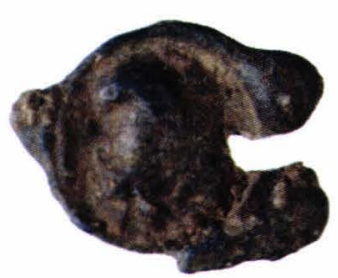

a.

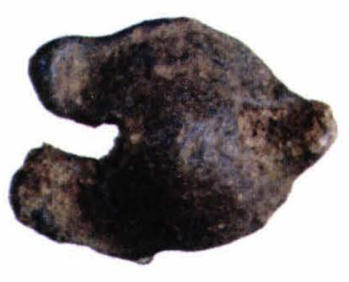

b.

8.

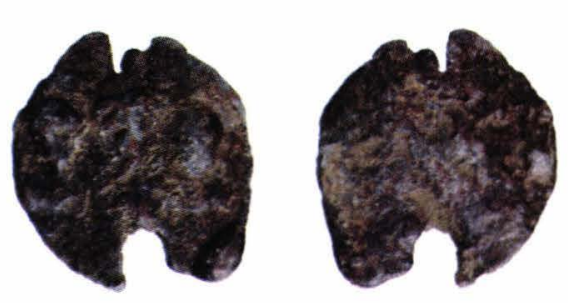

a.

10.

b.

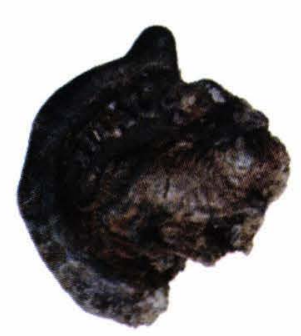

a.

11.

12.

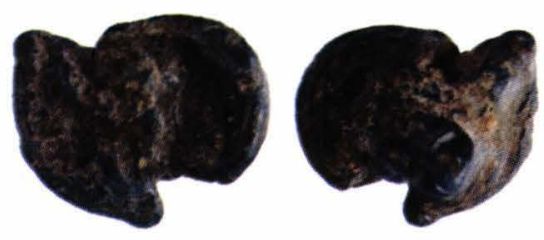

a.

b.

13.

Sigilii comerciale de la Tomis, nr. cat. 7-13

PI. II 